\title{
Evaluation of the contributions of possible sources to the leucosome of the diatexite of Socorro-Guaxupé Nappe, in the Alfenas Region, MG, Brazil
}

\author{
Lizeth Hernandez $\operatorname{Tasco}^{1}$ (D), Renato Moraes ${ }^{2 *}$ (D)
}

\begin{abstract}
The Socorro-Guaxupé Nappe crops out in southern Minas Gerais and it has an intermediate unit called Metaxite Unit, dominated by diatexites at its base, with large volumes of leucosome and schollen of stromatic garnet-biotite metatexite. Leucosome within the schollen crystallized via fractional crystallization and is dominated by plagioclase and quartz, although K-feldspar might be present. However, the larger volume of the coarse-grained leucosome, that dominates the unit, has granite, sometimes close to minimum granite composition. So, its formation, after partial melting, involved, segregation, fractional crystallization and accumulation. Proportions of leucosome / residue and leucosome / residue / peritectic phases indicate that the leucosome crystallized from more melt than a pelite source could produce, and probably diatexite worked as a pre-magmatic chamber and stocked melt produced from the granulites sitting at its bottom. Large proportion of biotite crystallized in the residue was formed due to equalization of water chemical potential between residue and leucosome.
\end{abstract}

KEYWORDS: Leucosome; melt crystallization; melt segregation; partial melting; Socorro-Guaxupé Nappe.

\section{INTRODUCTION}

Migmatites are high-grade metamorphic rocks formed by partial melting and are divided into two main types, metatexite and diatexite (Sawyer 2008). The main difference between them is the balance between the degree of partial melting and melt fraction left behind, after melt segregation, is generated due to deformation, which may also destroy the coherence of the tectonic structure of the protolith (Sawyer 2008). In metatexite, the pre-anatectic structure is preserved, whereas, in diatexite it is not. The generated melt during partial melting can either remain unsegregated from its residue, or be totally or partially segregated, allocated and crystallized in dilational structures, forming the leucosome, or even be removed from the system, forming dykes or larger granite bodies in shallower continental crust (Sawyer 1998, 2008).

The study of diatexite is fundamental, because their presence deeply affects the behavior of the lower crust (Jamieson et al. 2011), and, if deformed, it implies that its neosome crystallized, forming a network of solid touching-crystals before solid-state deformation started to be recorded, especially in quartz, which in many diatexites and granites seems

\footnotetext{
${ }^{1}$ Programa Geociências (Mineralogia e Petrologia), Instituto de Geociências, Universidade de São Paulo - São Paulo (SP), Brazil. E-mail: lhdeztasco@usp.br

${ }^{2}$ Departamento de Mineralogia e Geotectônica, Instituto de Geociências, Universidade de São Paulo - São Paulo (SP), Brazil.

E-mail: rmoraes@usp.br

${ }^{*}$ Corresponding author.
}

to be the last phase to crystallize. Part of the rheology control is made through fertility, water content and temperature, which control the degree of partial melting. However, in a rock already submitted to extensive partial melting, evaluating whether all the present leucosome was generated in situ, due to partial melting of a homogeneous source, in a closed or open system, is not an easy or direct task, as some diatexites might represent sites of melt accumulation rather than complete closed systems (Sawyer 2015).

In southern Minas Gerais, Brazil, the base of the Metatexite Unit of the Socorro-Guaxupé Nappe is an excellent example of diatexite with voluminous leucosome and abundant fragment of schollen, either of its residue or mafic granulite, locally with layers of transitional stromatic migmatite. One of the best outcrops of this unit occurs in an inactive quarry on the road between Alfenas and Machado, from where a complex history was recently revealed by a petrochronology study using zircon and monazite ages and chemistry (Rocha et al. 2017). As the rock is composed of more than $50 \%$ of leucosome, including undeformed to deformed types, bearing garnet and orthopyroxene, and with large variation in bulk composition, it represents an ideal laboratory to evaluate whether the processes of partial melting, segregation and crystallization occurred in an open or closed system and what was the role of deformation in it.

\section{GEOLOGICAL CONTEXT}

The Brasilia Orogen has been interpreted as the result of the neoproterozoic collision between the passive margin of the São Francisco and the active margin of the Paranapanema 
paleocontinents (Campos Neto \& Caby 2000). The units composed of sedimentary and metasedimentary rocks show that tectonic deformation and metamorphism increase from east to west, varying from absence of metamorphism in the cratonic portion, to amphibolite and granulite facies to the west, with rocks associated to a magmatic arc installed at its westernmost side (Fuck et al. 2017, Trouw et al. 1998, Campos Neto \& Caby 1999). The tectonic vergence is toward São Francisco Craton and is marked by oriented N-S thrusts (Dardenne 2000). Metamorphic foliation presents gentle SW-dipping, associated with stretching lineation, which dips to WNW or ENE, presenting a thrust kinematics parallel to the southern border of the São Francisco Craton (Campos Neto et al.2011).

At the southernmost portion of the Brasilia Orogen, is the Socorro-Guaxupé Nappe, which crops out to the south of São Francisco Craton (Fig. 1). It is derived from a plutonic magmatic arc with high-pressure felsic to mafic granulites, which change to metatexites and diatexites units toward the top unit of the structure, all of them cut by several granite and charnockite bodies (Campos Neto \& Caby 1999, 2000, Janasi 2002). The metatexite unit is dominated by metasedimentary protoliths (Campos Neto \& Caby 1999, 2000); at its bottom, it is dominated by diatexites that are the focus of the present investigation. Ultrahigh temperature conditions of metamorphism are determined for granulites at the base and for metatexites and diatexites at the intermediate portion of the nappe with temperatures higher than $950^{\circ} \mathrm{C}$ and pressures of $\sim 10 \mathrm{kbar}$ (Del Lama et al. 2000,
Moraes et al.2015, Rocha et al.2017, Tedeschi 2018, Rocha et al. 2018). In mangerite leucosomes from the Diatexite Unit and charno-enderbite leucosomes of the Metatexite and Granulite Units were formed via hornblende-dehydration melting reactions, which suggest temperatures between 850 and $900{ }^{\circ} \mathrm{C}$, and the absence of peritectic garnet indicates pressures below $10 \mathrm{kbar}$ (Salazar Mora et al. 2014).

An extensive set of geochronological data is available for the Socorro-Guaxupé Nappe, but their review is beyond the scope of this paper. However, recent data shows that the metamorphic peak occurred at $630 \mathrm{Ma}$, but main episodes of zircon crystallization in diatexites occurred at 612,608 and $600 \mathrm{Ma}$ (Rocha et al. 2017, 2018). Sm-Nd data suggests older sources (1.6-2.3 Ga) are involved in the genesis of these rocks (Janasi 2002). Genesis of the igneous protoliths has been related to a magmatic arc (Campos Neto 2000) and the lack of juvenile rocks related to the arc magmatism is pointed as a result of involvement of an anomalous enriched mantle source in the genesis of these rocks (Rocha et al. 2018). Field relationship suggests that the leucosome from the Metatexite Unit to be syntectonic and syn-collisional exhumation in the presence of anatectic melt between 625 and $610 \mathrm{Ma}$ (Salazar Mora et al. 2014, Rocha et al. 2017). A recent work has detected zircon grains with archean and paleoproterozoic ages within some of these granulites, which demonstrate a few layers of older rocks do exist within the Socorro-Guaxupé Nappe (Tedeschi et al. 2018), indicating a possible source of crustal contamination.

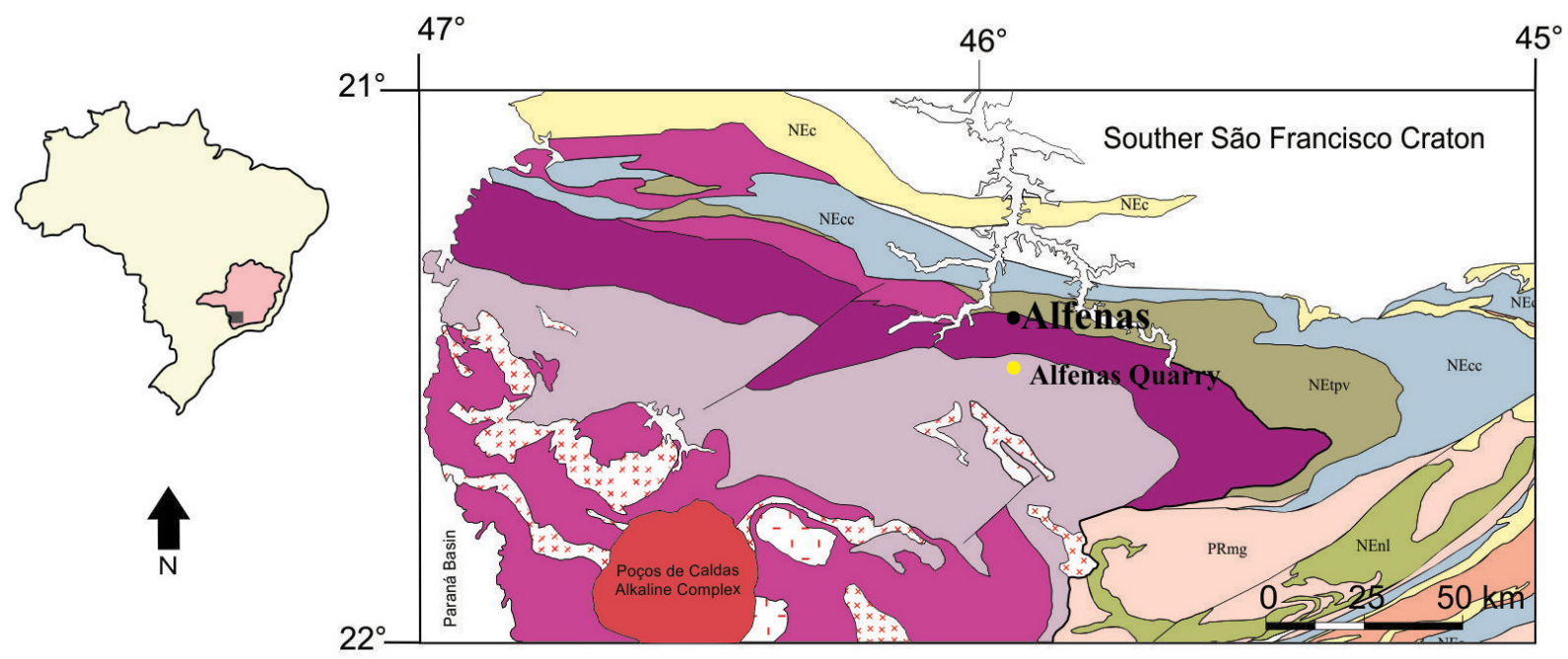

São Francisco Plate and Andrelândia Terrane Carrancas Nappe System (NEc)

\begin{tabular}{|c|c|}
\hline $\mathrm{Neo}$ & proterozoic-Ediacaran \\
\hline & Carmo da Cachoeira Nappe (NEcc) \\
\hline & Liberdade nappe (NEnl) \\
\hline & Granulitic allochthon (NEtpv: Três Pontas-Varginha Nappe) \\
\hline Pale & oproterozoic-Rhyacian \\
\hline & Calk-alkaline orthogneisses from island-arc complex (PRn \\
\hline & Migmatitic orthogneisses (PRgn) \\
\hline
\end{tabular}

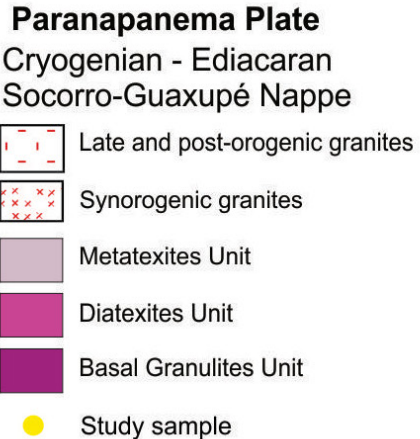

Figure 1. Geological map of the Southern Brasilia Orogen with the location of the study area (cut and modified from Campos Neto et al. 2011). 


\section{OBJECTIVE, MATERIALS AND METHODS}

The main objective of the present research was to understand whether the amount of leucosome observed in the diatexite was formed from a single protolith, in a closed or open system.

The investigation of segregation and crystallization of melt into leucosome was done by petrographic analysis and modal counting of forty-seven thin sections of the different parts of the diatexite, including schollen of stromatic residue and leucosome. Modal counting was made in the fieldwork on eleven parts of the wall of the quarry for a very coarse-grained leucosome, where grain size is larger than $1 \mathrm{~cm}$. This voluminous leucosome that dominates the outcrop in this unit is very coarse grained and it is difficult even to do thin sections of some of its portions, thus, the modal counting was made on quarry wall, as it is easy to recognize quartz and both feldspars with lens or naked eye. For comparison purposes, the in situ leucosome and their respective residues, from the stromatic schollen, with thickness from 0.3 to $0.5 \mathrm{~mm}$, were drawn and separated from each other, in seventeen selected thin sections, in order to do the modal proportion of the phases, using an optical microscope.

The calculation of the percentage of melt was made using estimates of relative volume of leucosome observed in the field, hand specimen and thin sections, as well as comparing the percentage of peritectic phases, residue, and possible amount of related produced melt from them. Subsequently, these results are compared with calculations made with THERMOCALC, version 3.40, in the chemical model system NCKFMASHTO $\left(\mathrm{Na}_{2} \mathrm{O}\right.$ $\left.\mathrm{CaO}-\mathrm{K}_{2} \mathrm{O}-\mathrm{FeO}-\mathrm{MgO}-\mathrm{Al}_{2} \mathrm{O}_{3}-\mathrm{SiO}_{2}-\mathrm{H}_{2} \mathrm{O}-\mathrm{TiO}_{2}-\mathrm{O}_{2}\right)$, using the new data set ds62 (Holland \& Powell 2011) and two bulk-sedimentary compositions, greywacke and shale, to evaluate the amount of melt each one can produce in a fixed P-T condition. Their bulk compositions were compiled from Condie (1993), whose values in weight \% were converted to mol \%, and simplified to the chemical system NCKFMASHTO (Tab. 1).

\section{ROCK DESCRIPTION IN THE FIELD AND PETROGRAPHY}

The study quarry is composed of diatexite dominated by coarse-grained leucosome with schollen of stromatic garnet-biotite metatexite ( 30 to $50 \mathrm{~cm}$ ), lenses of felsic and mafic granulite ( 1 to $5 \mathrm{~m}$ long), and stromatic diatexite (10 $\mathrm{m}$ thick). The presented work concentrated on the coarsegrained leucosome and associated schollen of stromatic biotite metatexite, which vary from a leucocratic to mesocratic residue, and garnet may reach $12 \%$.

\section{Schollen of stromatic garnet-biotite metatexite}

The schollen of stromatic garnet-biotite metatexite are fragments of random form and aspect ratio, with no preferred orientation when seen perpendicular to the stretching direction of late deformation (Fig. 2A). Although they might or might not be aligned by late deformation, when its aspect varies from schollen to schlieren (Fig. 2B), its internal structure is stromatic with banding defined by alternating residue and leucosome (Fig. 2C). Banding may present either a straight foliation or be folded (Fig. 2C); contacts with surrounding leucosome vary from sharp (Fig 2D) to partially digested (Fig. 2D), or to development of thick selvedge of coarse-grained biotite plus feldspars (Fig. 2E). Large crystals of garnet, up to $6 \mathrm{~cm}$ wide, occur in association with these schollen (Fig. 2F).

The schollen of stromatic biotite metatexite has inequigranular, fine to medium-grained fabric. The mineral assemblage comprises quartz, plagioclase, garnet, biotite, with minor amounts of K-feldspar (Fig. 3A), and zircon, apatite, monazite and opaque minerals occur as accessory phases. Muscovite flakes, chlorite and carbonate minerals are common, but not abundant, and are retrograde phases. Quartz forms anhedral crystals, undulose extinction, sometimes with chessboard patterns, although polygonal equigranular grains occur in the matrix. Although straight contacts close to $120^{\circ}$ are more common, very low, close to cuspate contacts are not uncommon, and there might be grains mimicking low

Table 1. Proportion of melt (\% melt.) and peritectic garnet (\% pGrt.) calculated by THERMOCALC compared to estimates in outcrop, hand specimen and thin section.

\begin{tabular}{|c|c|c|c|c|c|c|}
\hline \multirow{3}{*}{$\begin{array}{l}T\left({ }^{\circ} \mathbf{C}\right) \\
\text { at } 9 \mathrm{kbar}\end{array}$} & \multicolumn{6}{|c|}{ THERMOCALC } \\
\hline & \multicolumn{3}{|c|}{ greywacke } & \multicolumn{3}{|c|}{ shale } \\
\hline & $\%$ melt. & \% pGrt. & $\%$ melt. $/ \%$ pGrt. & $\%$ melt. & $\%$ pGrt. & $\%$ melt. $/ \%$ pGrt. \\
\hline 800 & 16 & 19 & 0.84 & $27^{*}$ & $25^{*}$ & 1.08 \\
\hline 840 & 19 & 18 & 1.06 & $36^{*}$ & $28^{*}$ & 1.29 \\
\hline 900 & 25 & 17 & 1.47 & 53 & 27 & 1.96 \\
\hline 950 & 34 & 15 & 2.27 & 58 & 25 & 2.32 \\
\hline \multirow{2}{*}{ SCALE } & \multicolumn{6}{|c|}{ ESTIMATES } \\
\hline & \multicolumn{2}{|c|}{$\%$ melt. } & \multicolumn{2}{|c|}{$\%$ pGrt. } & \multicolumn{2}{|c|}{$\%$ melt./\% pGrt. } \\
\hline Outcrop & \multicolumn{2}{|c|}{65} & \multicolumn{2}{|c|}{7} & \multicolumn{2}{|c|}{9.28} \\
\hline Hand specimen & \multicolumn{2}{|c|}{41} & \multicolumn{2}{|c|}{10} & \multicolumn{2}{|c|}{4.10} \\
\hline Thin section & \multicolumn{2}{|c|}{40} & \multicolumn{2}{|c|}{11} & \multicolumn{2}{|c|}{3.63} \\
\hline
\end{tabular}

Paragenesis for greywacke Grt $+\mathrm{Ksp}+\mathrm{Opx}+\mathrm{Pl}+\mathrm{Liq}$ and shale $\mathrm{Grt}+\mathrm{Sill}+\mathrm{Rt}+\mathrm{Ilm}+\mathrm{Liq},{ }^{*}$ corresponding to the paragenesis $\mathrm{Bt}+\mathrm{Grt}+\mathrm{Ksp}+\mathrm{Sill}+\mathrm{Rt}+\mathrm{Liq}$. 
dihedral angle of liquid-solid of trapped melt, as described in other migmatites (Holness \& Sawyer 2008). The plagioclase occurs as euhedral to subhedral crystals often present as antiperthite (3-4 mm), but it also occurs as polygonal very fine grains. Biotite is dark red, forms subhedral crystals, and is observed in the foliation, when lobed edges are observed; random crystals also occur, and these are shorter and of sharp boundaries, with thin films of quartz and feldspar, which mimic trapped melt films. K-feldspar occurs in two polymorphs, orthoclase and microcline. Muscovite occurs at rims and fractures of K-feldspar, whereas chlorite is a common phase that replaced biotite. Garnet is rounded, anhedral, has rounded inclusions of biotite and oval ones of quartz and feldspars; its rims are frequently replaced by biotite plus quartz intergrowths. Zircon, monazite and apatite have complex texture relationships; a detailed description and their petrochronological evolution are presented by Rocha et al. (2017).
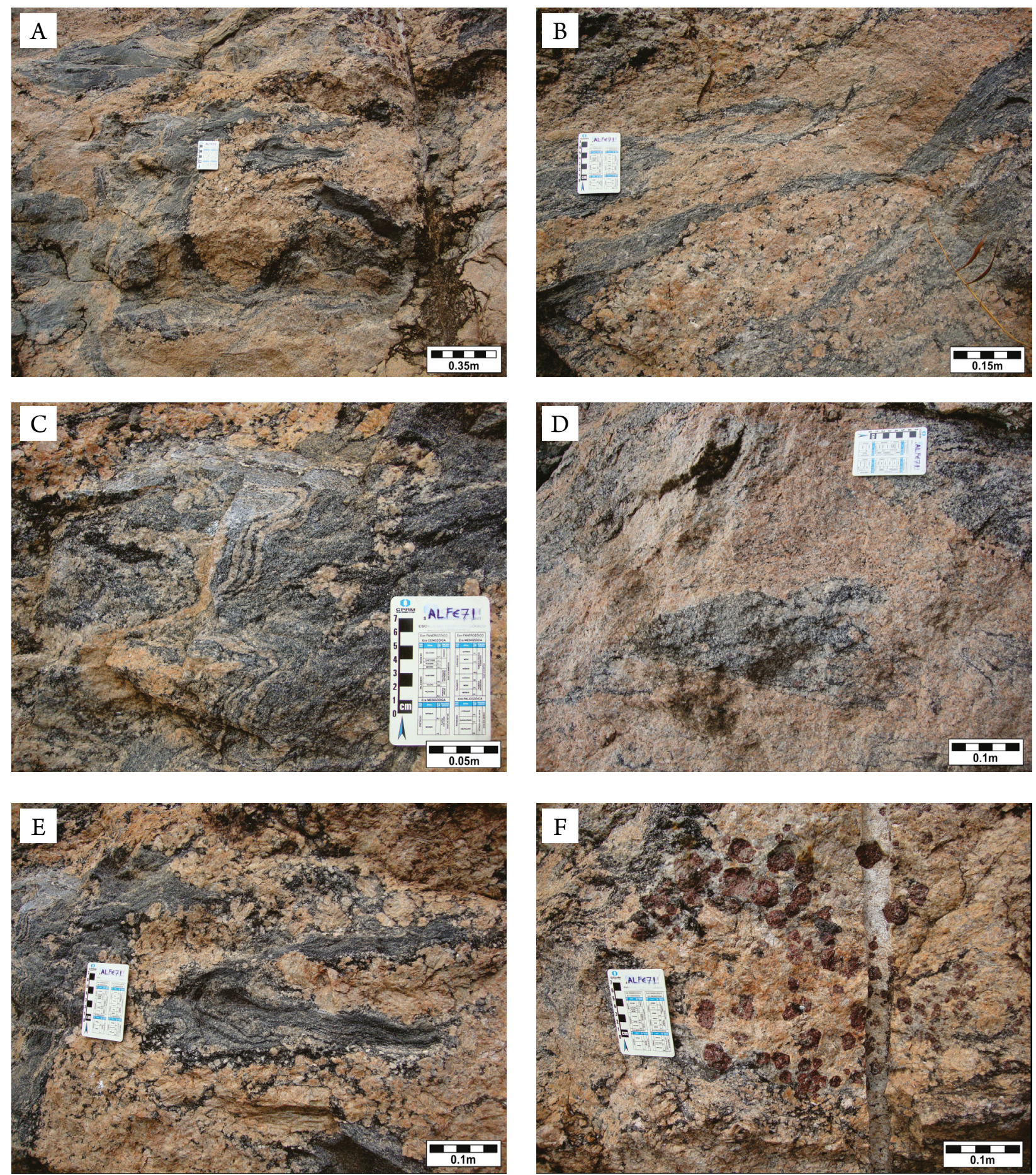

Figure 2. General characteristic in the field of garnet-biotite metatexite. (A) General occurrence of schollen with no preferred orientation. (B) Schlieren structure with concentration of biotite. (C) Schollen with stromatic folded structure defined by alternation of fine layers of residue and leucosome. (D) The schollen contacts with leucosome vary from sharp to irregular. (E) Thick selvedge developed at the border of a schollen; it is composed by biotite, K-feldspar, apatite, monazite and zircon. This is a detail from photo A. (F) Concentration of euhedral garnet porphyroblasts within the very coarse-grained leucosome. 


\section{Felsic granulite}

Felsic granulite occurs as shapeless to elongated blocks within the leucosome, with sharp contacts. It is a fine to medium grained inequigranular, granolepidoblastic rock, with orthopyroxene and garnet porphyroblasts. It is characterized by the mineral assemblage quartz, plagioclase, K-feldspar, orthopyroxene, garnet, and biotite (Fig. 3B). Zircon, apatite, monazite and opaque minerals are present as accessory phases. It commonly contains muscovite, chlorite and carbonate minerals, which occur as retrograde phases. The plagioclase and K-feldspar consist of anhedral to subhedral grains with interlobate or ameboid boundaries and are commonly antiperthitic and perthitic, respectively. Myrmekite texture when both crystals are in contact are also observed. Quartz occurs as anhedral grains and may be interstitial or elongated. There are also evidences of intracrystalline deformation, like undulose extinction and recrystallization due to grain boundary migration, evidenced by its rounded shape contacts. Orthopyroxene occurs as subhedral elongated grains with rounded or pointed edges, less frequently with uralite alteration, and is replaced by symplectites of biotite + quartz and feldspars. The garnet is characterized by rounded porphyroblasts and contains quartz and feldspars inclusions; sometimes it has its rims replaced by symplectites of biotite with quartz and feldspars. Biotite is brownish-green and is oriented along the foliation, smaller secondary flakes are light-green and occur filling fractures in garnet or surrounding this mineral. The progressive textural re-equilibration is illustrated by a progressive increase in interfacial angle resulting in rounded corners on quartz and plagioclase mineral films.

\section{Leucosome}

Leucosome presents a wide compositional range, from plagioclase-rich granodiorite to syenogranite, with a wide variation in quartz content. It is observed in white, gray to pink colors, and thin layers ( $3 \mathrm{~mm}$ up to $5 \mathrm{~cm}$ thick), when present in the schollen of stromatic biotite metatexite, but it constitutes the larger volume of the diatexite in the whole outcrop. It has a phaneritic texture, sometimes of pegmatitic character. It is divided into three types, leucosome layers from inside schollen, and coarse and very-coarse grained leucosome that dominates the diatexite.

\section{Leucosome layers from the schollen of stromatic biotite metatexite}

The layers of leucosome from schollen of stromatic biotite metatexite are fine to medium grained and present composition varying from plagioclase-rich granodiorite to syenogranite composition, with a large variation in the amount of quartz. The main mineral assemblage is made of plagioclase and quartz with variable amounts of K-feldspar; whereas biotite and garnet are common mafic phases, orthopyroxene and hornblende are rare. Accessory phases are apatite, monazite zircon and opaque minerals. In general, contacts between leucosome and residue are transitional, marked by mildly gradual disappearance of biotite. Plagioclase is the most abundant mineral (Fig. 4A). It is euhedral to subhedral, with straight, rounded and cusped edges and most crystals are antiperthite. K-feldspar is inversely more abundant in relation to plagioclase and quartz (Fig. 4A), occurs as subhedral to anhedral crystals, as orthoclase or microcline and inclusions of euhedral to subhedral plagioclase (Fig. 4B). Myrmekite is common at contacts between both feldspar contacts. Quartz occurs as inclusions or as interstitial phase between other minerals (Fig. 4A). The main deformation microstructures are marked by chessboard and undulose extinction, bulging in the grain boundaries of quartz and deformation twins in plagioclase.

\section{Coarse-grained leucosome}

The coarse-grained leucosome has composition varying from granodiorite, to syenogranite. The mineral assemblage is composed of $\mathrm{K}$-feldspar, plagioclase, and quartz (Fig. 4C), with variable amounts of biotite, garnet, orthopyroxene, and minor amounts of hornblende, apatite, monazite, zircon and opaque minerals. K-feldspar and plagioclase occur either as euhedral or subhedral crystals (Fig. 4D), with straight, lobed and cusp edges, sometimes forming interfacial angles of less than $60^{\circ}$ with quartz crystals. K-feldspar occurs as two
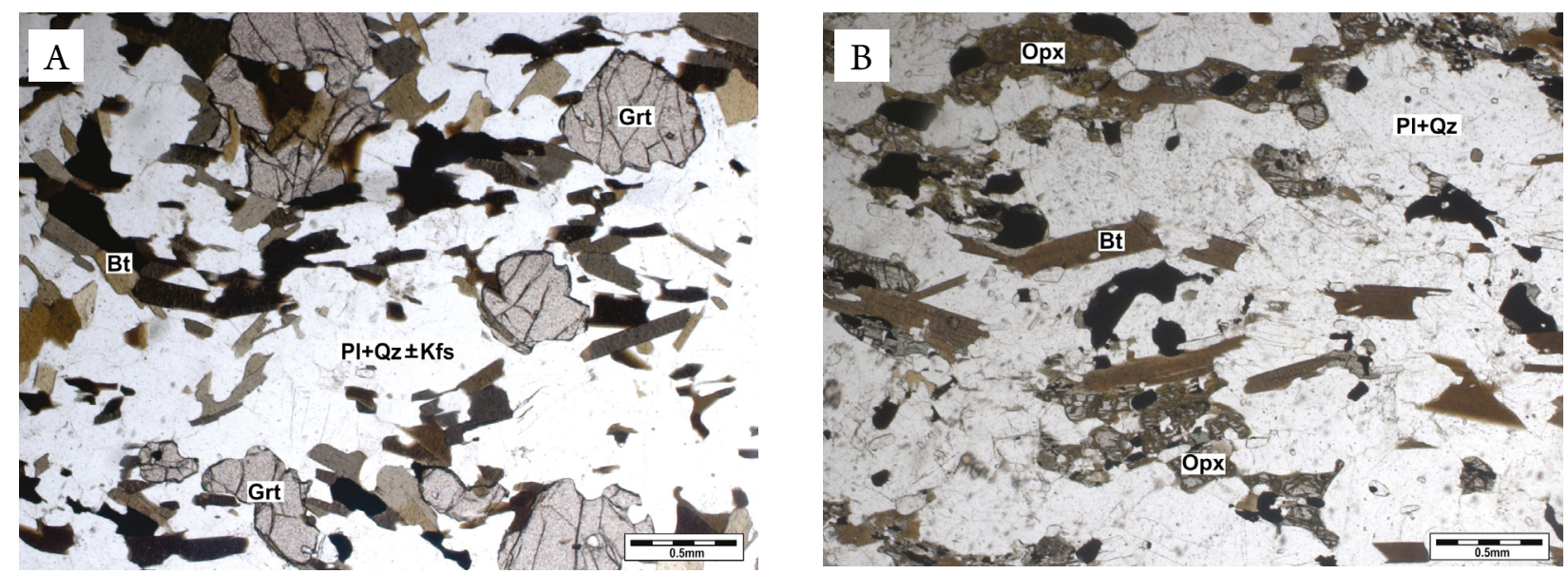

Figure 3. Photomicrographs of two types of residue. (A) Layer of garnet-biotite metatexite from a schollen; parallel polarized light, ALFE-71E1. (B) Felsic granulite with characteristic mineral assemblage, and late biotite; parallel polarized light, DE3-11C. 
polymorphs, orthoclase and microcline, and occasionally, as perthite with abundant exsolution lamellae. Inclusions of rounded or anhedral quartz and euhedral to subhedral plagioclase are common (Fig. 4E). Quartz is an interstitial phase, and chessboard and undulatory extinction are common. Garnet contains biotite, quartz and anhedral feldspars inclusions, with rims replaced by biotite, quartz, and feldspars symplectites (Fig. 4F). Orthopyroxene occurs as 0.1 to $0.5 \mathrm{~cm}$-long grains, with rims, sometimes replaced by a very fine-grained combination of colorless and green amphiboles, probably anthophyllite and hornblende, which are associated with opaque minerals (Fig. 4F).

\section{Very coarse-grained leucosome}

The composition of very coarse-grained leucosome varies between monzogranite to syenogranite, and is the most abundant leucosome-facies in the study area. Its color varies from grey, to white to dominantly pink, grain size varies from
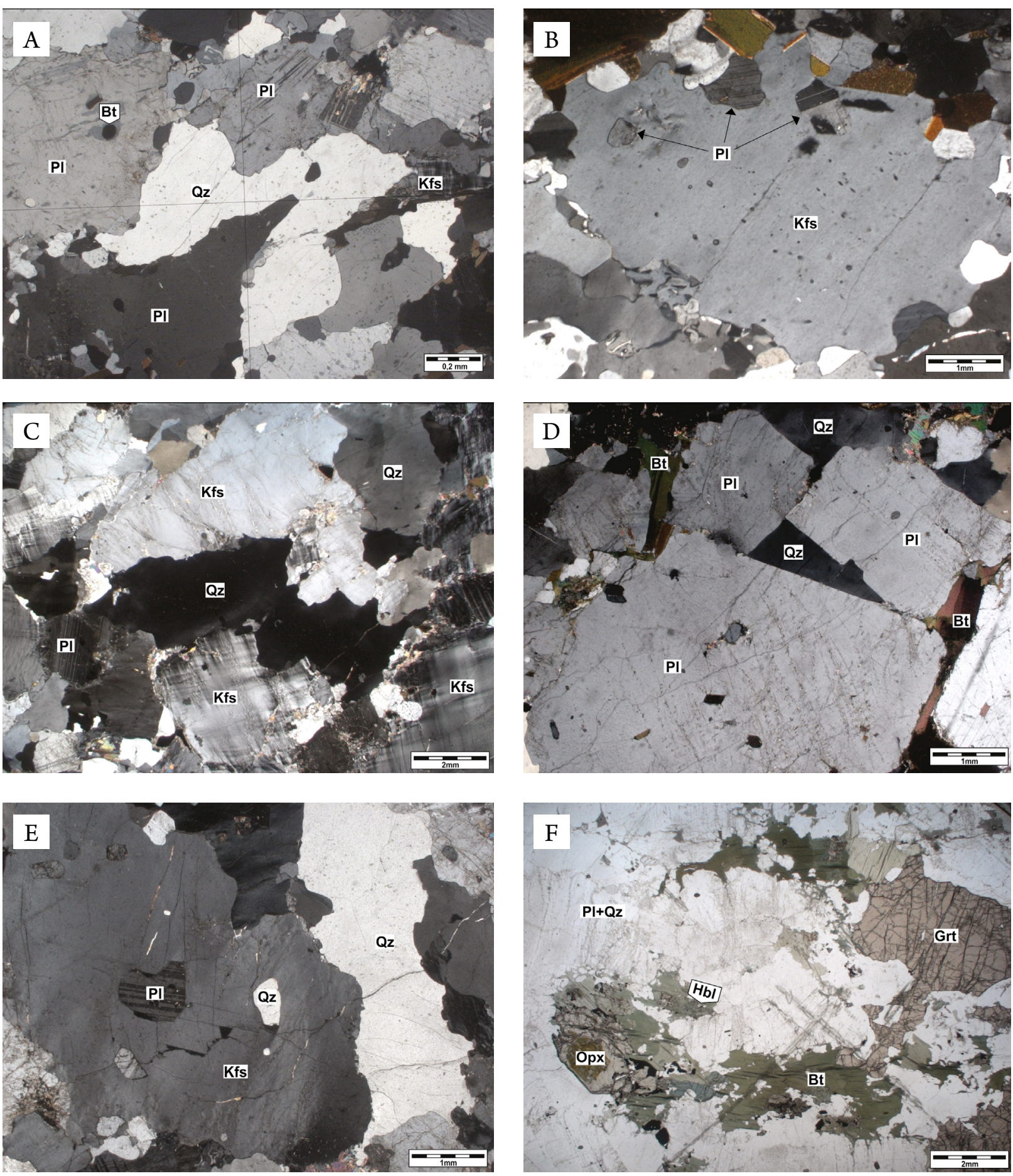

Figure 4. Photomicrographs of leucosome features and types. (A) Leucosome layer from the schollen of stromatic biotite metatexite, mainly constituted by plagioclase and quartz with minor amounts of late K-feldspar; crossed polarized light, MGR-12F. (B) Plagioclase inclusions inside K-feldspar crystal, crossed polarized light, DE3-3B1. (C) The typical felsic coarse-grained leucosome composition, rich in K-feldspar and quartz; crossed polarized light, DE3-11B2-2. (D) Euhedral plagioclase crystals with interstitial quartz and biotite, crossed polarized light, ALFE-71G2. (E) Shapeless or rounded inclusions of plagioclase and quartz inside K-feldspar; crossed polarized light, MGR-12B. (F) Orthopyroxene and garnet inside plagioclase + quartz leucosome both partially replaced, respectively, by hornblende and biotite; parallel polarized light, ALFE-71G2. 
very coarse grained to pegmatitic. The mineral assemblage is composed of quartz, $\mathrm{K}$-feldspar and plagioclase with biotite, garnet, and pyrite. The plagioclase occurs as euhedral or subhedral crystals, as inclusions in K-feldspar mega crystals, and in the matrix, it is an early phase to crystallize, denoting a long crystallization history. K-feldspar occurs as either small to larger than $5 \mathrm{~cm}$ phenocrysts, whereas quartz is interstitial and, therefore, the last phase to crystallize. Garnet occurs as 1 to $7 \mathrm{~cm}$ euhedral to subhedral crystals, representing the generation of peritectic porphyroblasts, due to biotite breakdown melting. In some parts, the late biotite is observed surrounding the K-feldspar phenocrysts and garnet.

\section{LIQUID SEGREGATION AND CRYSTALLIZATION}

Petrogenetic processes that lead into the formation of diatexites allow to understand what happens when a large volume of melt is formed, involving partial melting, segregation from a layered source, and subsequent crystallization, and the investigation of its leucosome can help this understanding. Here, at least two main rock types can be considered as sources for the melt, garnet-biotite gneiss and the felsic granulite, respectively, with immature sedimentary and igneous rocks protoliths, with the first one being the dominant rock in the outcrop and within the unit. Although some lenses of mafic granulite also occur in this quarry and regionally, the amount of melt produced was low, and therefore, not significant. The layers of stromatic diatexite have a well-preserved structure, suggesting that either generated melt was preserved within it without destroying its layering or, if it was lost to the major volume of leucosome around, it happened in such a low rate that its structure was undisturbed (Rosenberg \& Handy 2005).

The modal proportion was determined in very coarsegrained, coarse-grained and layers of leucosome from schollen, felsic granulite, as well as in their respective residues. Despite some variation in composition, some general lines can be hints on composition and leucosome types.

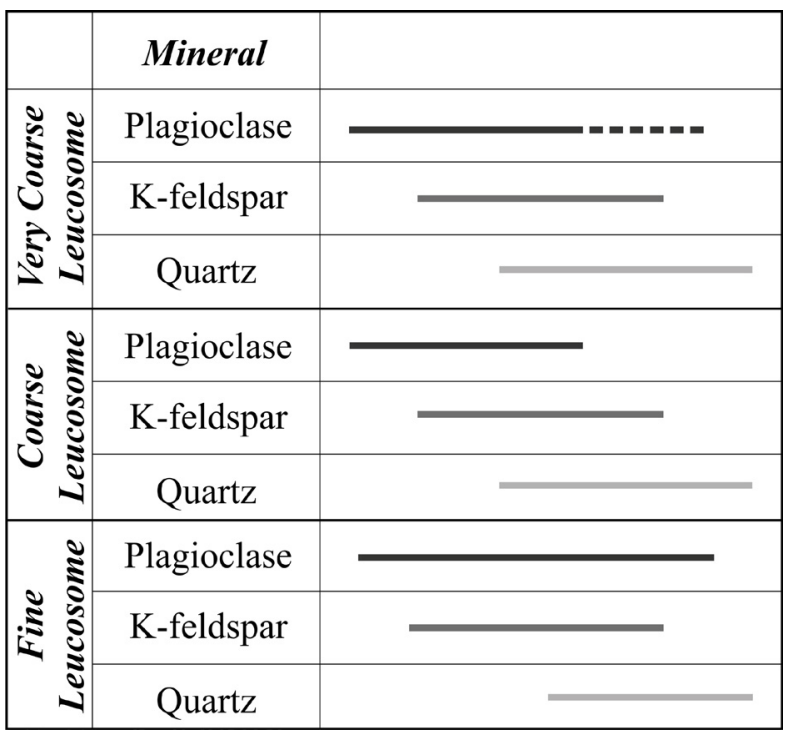

Figure 5. The crystallization sequence of felsic minerals in each leucosome types.
In situ leucosome in felsic granulite is not as common and voluminous as in the schollen, but it occurs and has modal composition of granodiorite. It might be orthopyroxene-bearing, just as its host granulite, and also have garnet. It is coarse-grained and plagioclase is euhedral to subhedral, the earliest phase to crystallize, sometimes occurring as inclusion inside K-feldspar, with quartz as the latest interstitial phase (Fig. 5). Some coarse-grained leucosomes are very similar to this type, richer in plagioclase and in mafic minerals, mainly garnet, orthopyroxene, hornblende and biotite, with variable amounts of K-feldspar and quartz. Plagioclase is the earliest felsic phase to crystallize, followed by K-feldspar and quartz (Fig. 5). In some leucosome layers, plagioclase and quartz form cumulates and might or might not have late K-feldspar. In all cases, the last phase consists of quartz (Fig. 5).

The layers related to schollen of stromatic biotite metatexite are the richest in plagioclase, even if they might have $\mathrm{K}$-feldspar, their main compositional variation is related to the amount of quartz, varying from granodiorite, poor in quartz, to samples with more than $55 \%$ modal quartz. The layers rich in K-feldspar have composition into syenogranite field (Fig. 5). The texture indicates that the layers very rich in plagioclase and quartz are cumulates, formed mainly by fractional crystallization and subsequent removal of the fractionated melt rich in potassium and silica. Some layers, however, present granite composition with early crystallization of plagioclase and quartz, followed by K-feldspar plus some plagioclase and quartz as a later phase, and therefore, these may represent the closest composition to the initial anatectic melt (Carvalho et al. 2016).

The very coarse-grained leucosome may contain biotite, biotite and garnet, or garnet porphyroblasts of 5 to $7 \mathrm{~cm}$, which allows to infer biotite breakdown reaction as the main partial melting reaction to produce melt and diatexite. Pressure must be higher than $10 \mathrm{kbar}$, as no cordierite is observed and it is consistent with thermobarometric calculations in rocks of this outcrop (Rocha et al. 2017). Its composition is broadly granite (Fig. 6), although in some places there are agglomerates of plagioclase, moving its composition into monzogranite field (Fig. 6). The crystallization

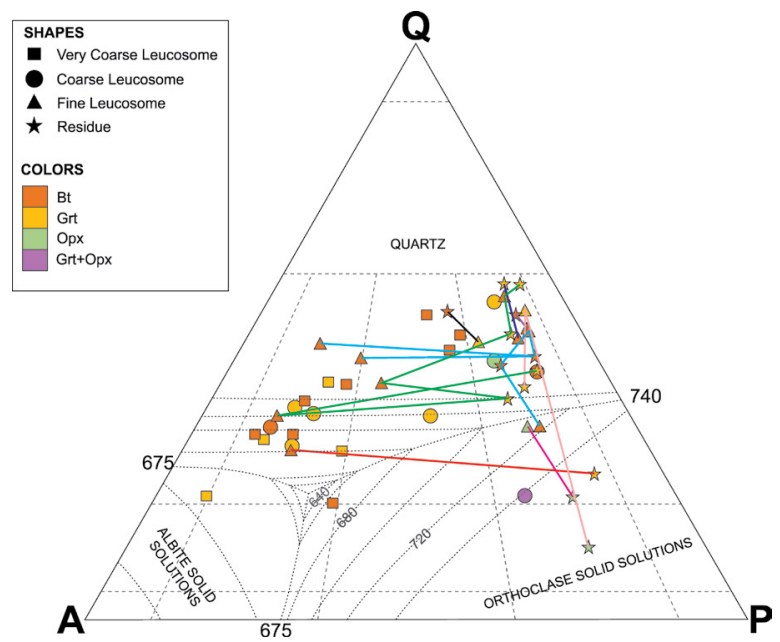

Figure 6. QAP diagram of the mineral modal percentage of in leucosome types and related residues, when available. A tie line connects a residue with leucosome symbols that are from the same thin section. The isolines shows equilibrium diagram for the granite minimum at $10 \mathrm{~kb}$ from Luth et al. (1964). 
sequence is similar to what was observed in other parts, with plagioclase and biotite as early phases, followed by K-feldspar and interstitial quartz. In some portions, K-feldspar phenocrystals have concentrated early biotite along their crystallization, pushing formed crystals aside.

Although a large variety of all types of leucosome composition is observed, a cluster close to the granite minimum composition of all types of leucosome does occur (Fig. 6), evidencing that despite of processes involved in melt formation, segregation from its source and continuous crystallization, it evolves toward the granite minimum (Fig. 6).

An evaluation of the amount of in situ leucosome, related residue and the amount of leucosome in the whole outcrop can provide evidence on whether the system was maintained closed or opened during the process of partial melting and

\section{1}
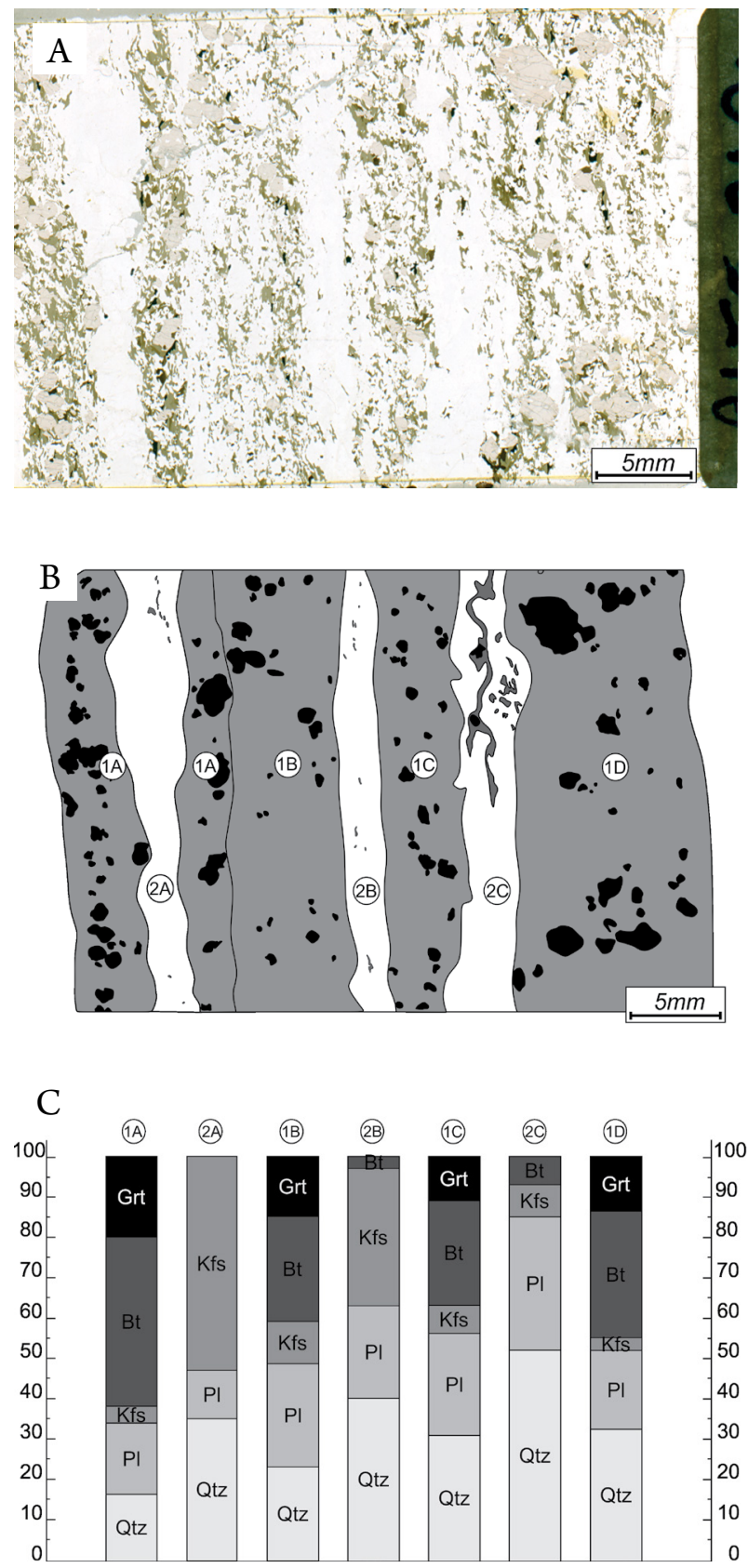

melt crystallization. It can be examined as the relationship between bulk rock composition, P-T conditions of partial melting, involved melt reaction, and the modal proportion of the produced peritectic phases can be traced and compared to what is observed in the outcrop. The investigation of this relationship was made via modal analyzes in thin sections (Figs. 7 and 8), in hand specimen (Fig. 9), in outcrop (Fig. 10 ), and then with simple thermodynamic modeling using THERMOCALC (Holland \& Powell 2011).

In two thin sections of schollen of stromatic biotite metatexite, observed proportions of residue plus garnet and leucosome are 77 and 23\%, and 69 and 31\% (Fig. 7), where garnet is, respectively 8 and 3\% (Fig. 7). These thin sections were made in portions where contacts between leucosome and residue are transitional to avoid any intrusive relationships

\section{2}

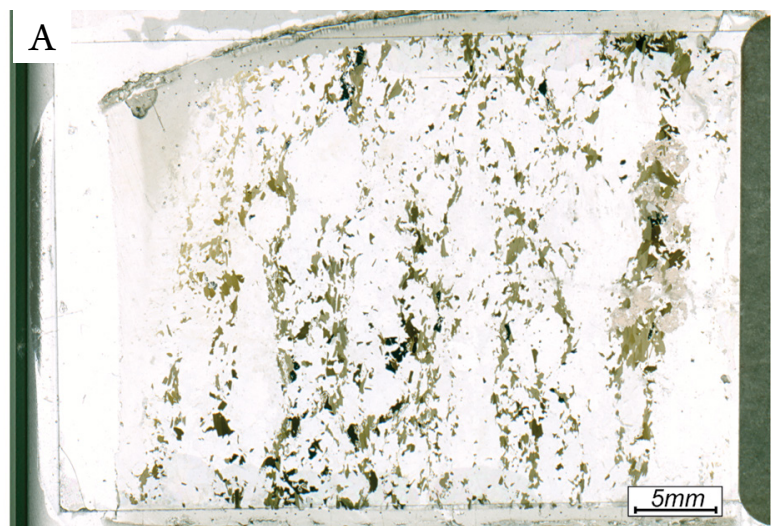

B
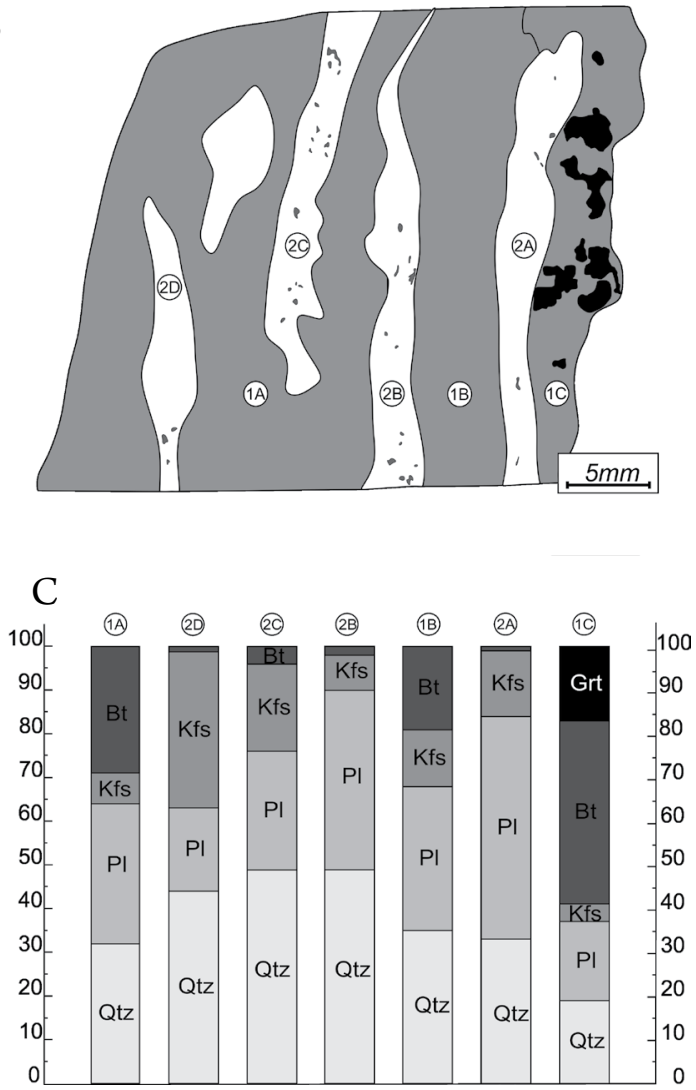

Figure 7. Comparison of the modal proportions between residue and leucosome layers in samples of schollen of stromatic biotite metatexite rich (1 - ALFE-71D1) or poor (2 - DE3-3B1-C) in garnet. In all three images (A) is a scan of the thin section (B) is a drawing of residue and garnet and leucosome (in white) and in (C) the modal proportions of garnet, biotite and felsic minerals from different layers. 
and to guarantee a relationship of in situ partial melting. Here, leucosome varies from granodiorite, with large amounts of quartz (22-56\%), to syenogranite (Figs. 6 and 7), with small amounts or no mafic phases, mainly biotite (0-7\%), and very minor amount of garnet (0-1\%) (Fig. 7). Even if some leucosome concentrates plagioclase, all residues are even richer in plagioclase, biotite, garnet and sometimes orthopyroxene and hornblende, and poorer in quartz and K-feldspar, which are concentrated in leucosome (Figs. 6 and 7). In the field, in one examined wall, the proportion of leucosome, residue and peritectic garnet (Fig. 10) is 60:30:10.

The modal amount of garnet determined within leucosome and residue either in adjacent layers or in outcrop (Figs. $7,8,9$ and 10) is not in accordance with calculated proportions of amount of peritectic garnet, melt and residue in a closed system with starting materials as pelite and greywacke.

In the pelite, the proportion of melt and peritectic phases, at $800{ }^{\circ} \mathrm{C}$ and $9 \mathrm{kbar}$ is approximately $1: 1$ and, at same pressure, but at $950^{\circ} \mathrm{C}$, it changes to $2: 1$, whereas, at same $P-T$ conditions, greywacke produces approximate ratios of 1.5:2 and 3.5:1.5 (Tab. 1). The proportions are calculated using average shale and greywacke compositions from Condie
(1993) by THERMOCALC, version 3.40, in the model system NCKFMASHTO ( $\mathrm{Na}_{2} \mathrm{O}-\mathrm{CaO}-\mathrm{K}_{2} \mathrm{O}-\mathrm{FeO}-\mathrm{MgO}-\mathrm{Al}_{2} \mathrm{O}_{3}-\mathrm{SiO}_{2}-$ $\mathrm{H}_{2} \mathrm{O}-\mathrm{TiO}_{2}-\mathrm{O}_{2}$ ), using the thermodynamic data set internally consistent ds62 (Holland \& Powell 2011). The mineral associations of granulite facies vary according to the sedimentary protolith, having orthopyroxene, garnet, K-feldspar, quartz, plagioclase and melt, whereas, for the shale, biotite, garnet, K-feldspar, sillimanite, quartz, rutile and melt coexist from 800 to $850^{\circ} \mathrm{C}$, but in the range of 900 to $950^{\circ} \mathrm{C}$, garnet, sillimanite, rutile, ilmenite and melt are the stable phases. All calculations were made at a pressure of $9 \mathrm{kbar}$ and modal proportions are present at Table 1 . The $P-T$ conditions to initiate the data processing done here are based on the temperature and pressure calculations presented by Rocha et al. (2017).

It is observed that the composition of the melt is similar to the one produced by the melting of the greywacke; however, the amount of leucosome can be compared to the amount of melt produced by shale, although it is smaller, being on average $53 \%$ for temperatures between 900 to 950 ${ }^{\circ} \mathrm{C}$. As the amount of silicate liquid necessary for the proportion of the leucosome observed in fieldwork is larger than $70 \%$, i.e., greater than that predicted by the model for a
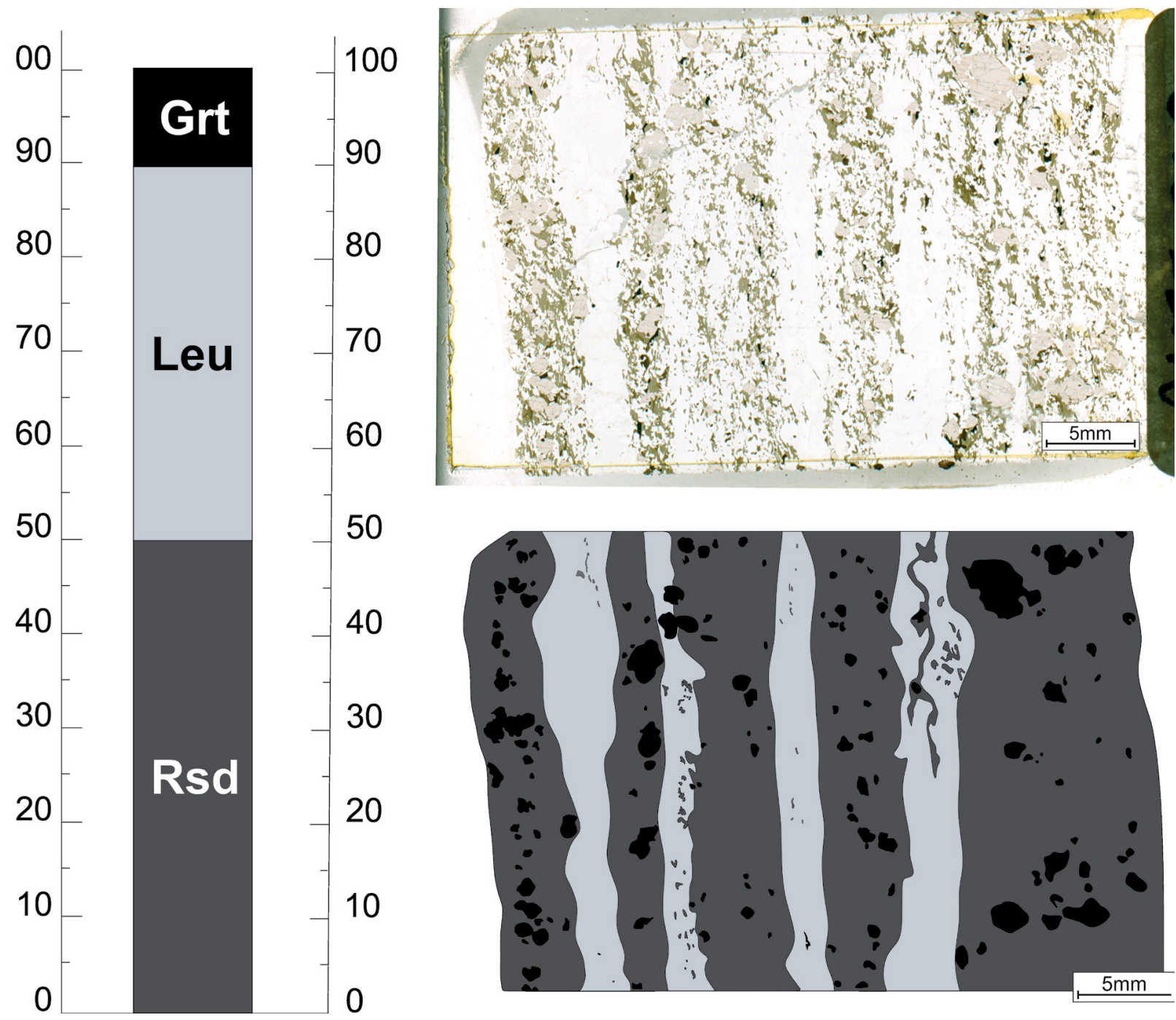

Figure 8. Proportions of the migmatite parts recognized in thin section and normalized to 100\%; peritectic garnet (Grt), leucosome (Leu) and residue (Rsd). 


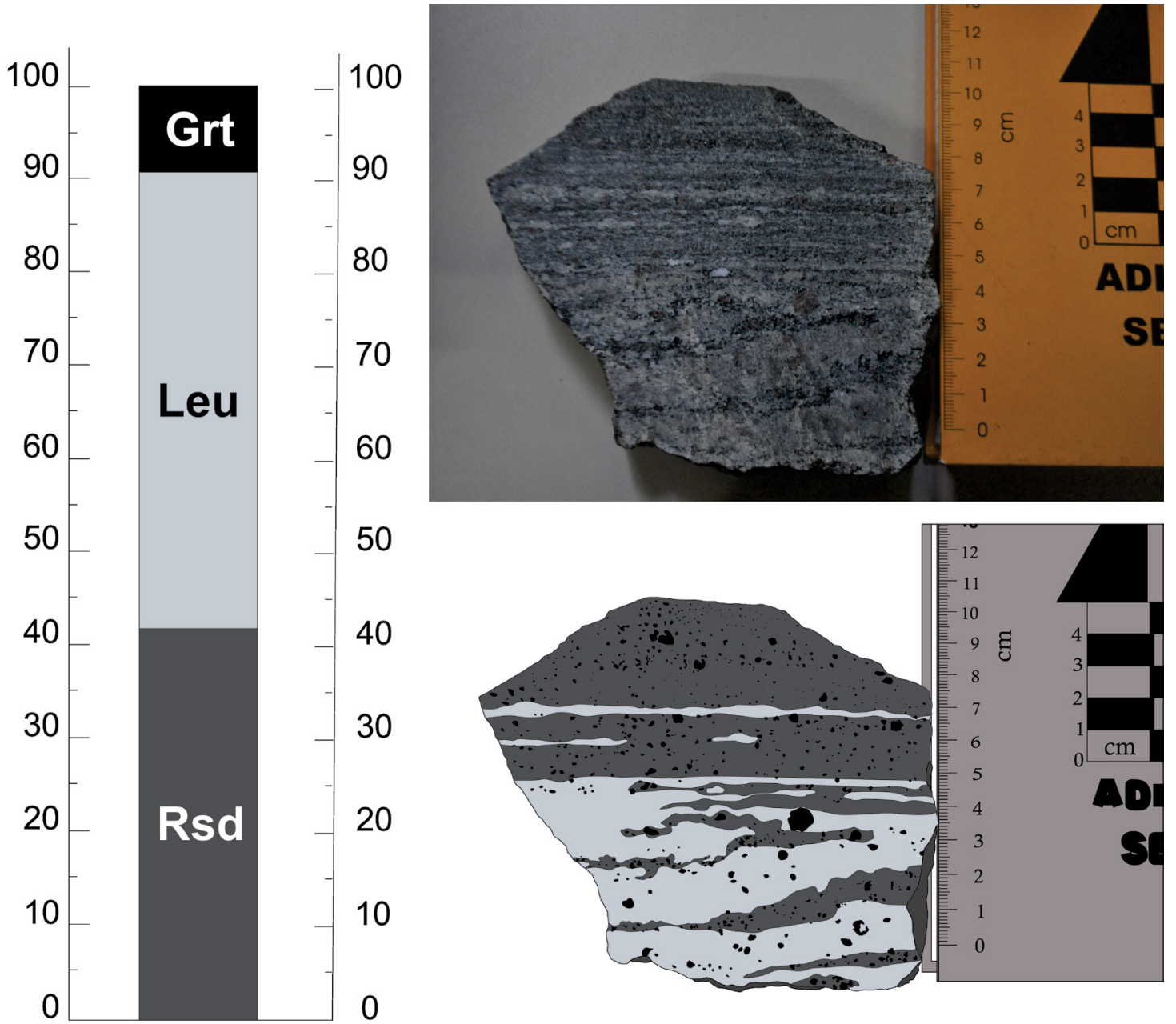

Figure 9. Proportions of the migmatite parts recognized in hand specimen and normalized to 100\%; peritectic garnet (Grt), leucosome (Leu) and residue (Rsd).

greywacke, being on average $30 \%$. Therefore, it is interpreted that there was an input of melt from other sources, possibly of neighboring units, whose center of segregation, accumulation and crystallization was the study diatexite. Water influx during partial melting also might improve the fertility of the rock, generating a larger amount of melt, as suggested before (Weinberg \& Hasalová 2015). However, water influx is something hard to prove as the bottom unit is a made up of drier rocks, mainly granulites, and up to this moment there is not a good water source or its exact channel way.

Another way to check if the system was closed or open for gain or loss of the melt is the proportion of peritectic phases and leucosome, if the latter represents the crystallized melt. Between 900 to $950^{\circ} \mathrm{C}$, pelite produces a proportion of peritectic phases to melt of 1:5. Though this is not observed in the outcrop, a much larger amount of leucosome is observed and a gain of melt in an open system can be inferred.

Also, due to the high melt accumulation in the diatexite, it can be seen as the formation of a pre-magmatic chamber. The diatexite can work as a feeding zone for the granite plutons formed at shallower crustal levels, in which the magma of a deeper level pervasively intrudes a high temperature metamorphic complex, most of the intruded magma will not freeze because of the prevailing temperature. The interaction between magma and country rocks, which could include partial melting and crystallization of the magma passing through, would modify magma to a more granitic composition, as found in the higher-level plutons (Olsen et al. 2004). Most residue is represented by schollen of stromatic biotite metatexite and a very large proportion of biotite is observed in these blocks and in some of them it is inversely proportional to the amount of K-feldspar (Fig. 7). Although some biotite might be defining a preferred orientation, the foliation, it is difficult to stablish if the biotite grew previous to the metamorphic peak, as a very large number of crystals are distributed randomly in the rock and they might be related to retrometamorphism. The consumption of garnet and production of biotite are carried out by reactions with the surrounding melt - as has been indicated and already recognized in those rocks (Rocha et al. 2017) - , which is probably also involved in the consumption of K-feldspar and water, the last from melt, with equalization of water chemical potential gradients between melt and residue, as discussed in a very elegant way by White and Powell (2010).

\section{CONCLUSIONS}

Investigated diatexites present a large volume of leucosome, which describe a history of segregation from its source, combined with melt fractional crystallization, formation of 

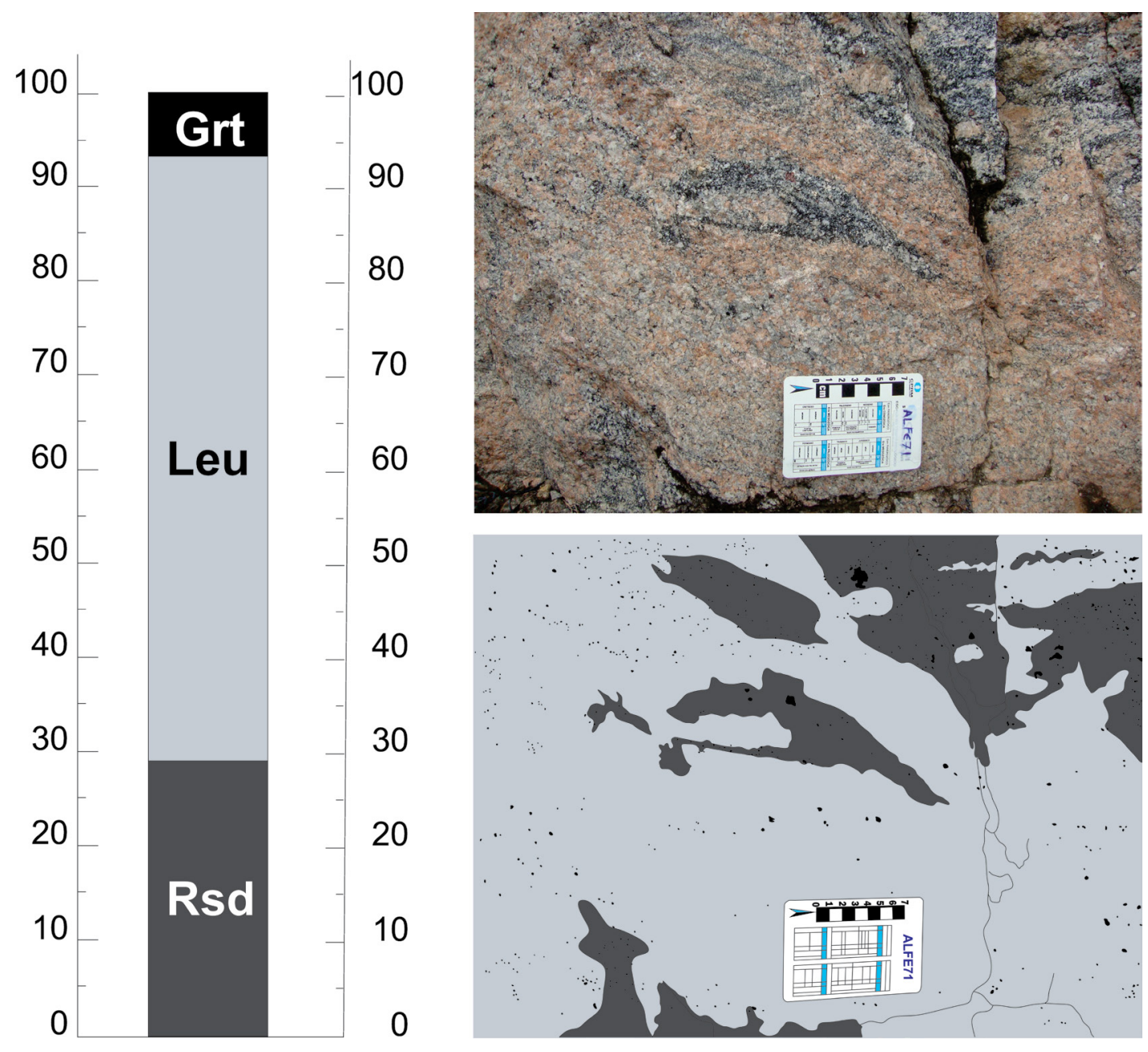

50

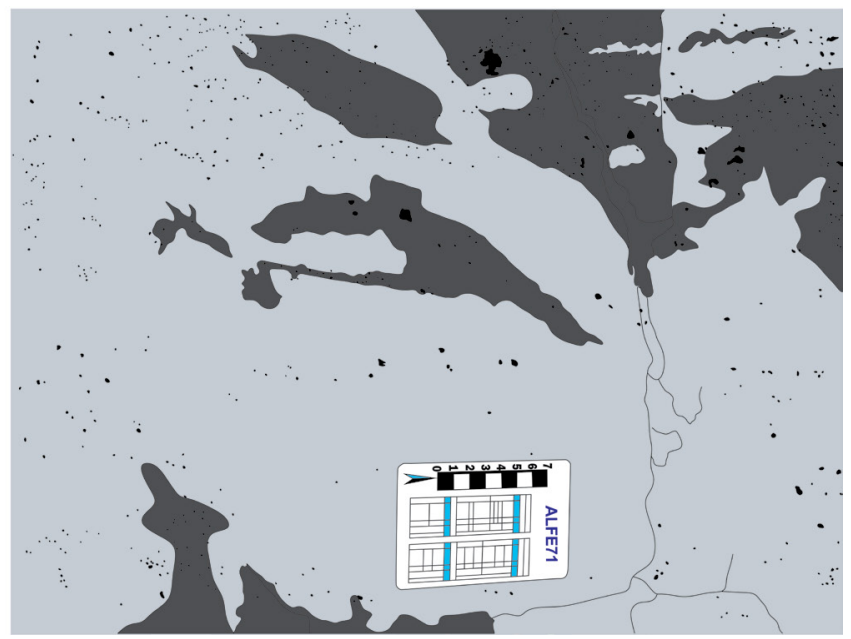

Figure 10. Proportions of the migmatite parts recognized in field and normalized to 100\%; peritectic garnet (Grt), leucosome (Leu) and schollen - residue (Rsd).

cumulates of wide range of composition, and crystallization of compositions closest to granite minimum.

The first steps of segregation are leucosome layers very rich in plagioclase and quartz, still within schollen of stromatic biotite metatexite, indicating they are cumulates, formed by fractional crystallization. After melt segregation and extraction, the segregated melt, which was richer in potassium and silica, starts to accumulate and its crystallization contributed to form the coarse and very coarse leucosome - richer in K-feldspar; the proportion of felsic minerals points to the granite minimum composition. Water influx also might have helped the partial melting, and along the cooling path an equilibration of water chemical potential between residue and leucosome was probably responsible to produce a residue richer in biotite and a drier leucosome, as suggested recently as mechanism to produce this kind of petrological pair in the literature (White \& Powell, 2010).
The amount of observed leucosome in the whole outcrop is much larger in volume than predicted by thermodynamic modeling from either pelite or greywacke as starting material. Its interpretation can suggest the formation of a pre-magmatic chamber, for there was an input of melt from other sources, and probably some of the melt generated from the granulites at the unit at the bottom migrated into the diatexite, which worked as an accumulation site for melt.

\section{ACKNOWLEDGEMENTS}

Authors would like to thank FAPESP for financial support (grant 16/22627-3), as well Brenda Chung Rocha and Elisa Levatti Alexandre for providing the samples and thin sections used in the present study. Constructive reviews by Bruna Borges Carvalho and Luana Moreira Florisbal are very much appreciated and improved the quality of the paper.

\section{ARTICLE INFORMATION}

Manuscript ID: 20180066. Received on: 06/07/2018. Approved on: 01/06/2019.

L. H. T. did field work, petrography, petrology and prepared the figures. R. M. provided guidance regarding Brazilian Geology and petrography, work on petrological aspects and took part in the field work as well.

Competing interests: The authors declare no competing interests. 
Braz. J. Geol., 49(1):e20180066

\section{REFERENCES}

Campos Neto M.C. 2000. Orogenic systems from southwestern Gondwana, an approach to Brasiliano-pan African Cycle and orogenic collage in southeastern Brazil. In: Cordani U.G., Milani E.J., Thomaz Filho A., Campos D.A. (eds.), Tectonic Evolution of South America. Rio de Janeiro, Brazil, 31st International Geological Congress, p. 335-365.

Campos Neto M.C., Basei M.A.S., Janasi V.A., Moraes R. 2011. Orogen migration and tectonic setting of the Andrelândia Nappe System: an Ediacaran western Gondwana collage, south of São Francisco Craton. Journal of South American Earth Sciences, 32(4):393-406. https://doi. org/10.1016/j.jsames.2011.02.006

Campos Neto M.C. \& Caby R. 1999. Neoproterozoic high-pressure metamorphism and tectonic constraint from the nappe system south of the São Francisco Craton, southeast Brazil. Precambrian Research, 97(1):3-26. http://doi.org/10.1016/S0301-9268(99)00010-8

Campos Neto M.C. \& Caby R. 2000. Terrane accretion and upward extrusion of high-pressure granulites in the Neoproterozoic nappes of southeast Brazil: Petrologic and structural constraints. Tectonics, 19(4):669687. https://doi.org/10.1029/1999TC900065

Carvalho B.B., Sawyer E.W., Janasi V.A. 2016. Crustal reworking in a shear zone: Transformation of metagranite to migmatite. Journal of Metamorphic Geology, 34(3):237-264. https://doi.org/10.1111/jmg.12180

Condie K.C. 1993. Chemical composition and evolution of the upper continental crust: contrasting results from surface samples and shales. Chemical Geology, 104(1-4):1-37. https://doi. org/10.1016/0009-2541(93)90140-E

Dardenne M.A. 2000. The Brasilia fold belt. In: Cordani U.G., Milani E.J., Thomaz Filho A., Campos D.A. (eds.), Tectonic Evolution of South America. Rio de Janeiro, 31st International Geological Congress, p. 231-236.

Del Lama E.A, Zanardo A., Oliveira M.A.F, Morales N. 2000. Exhumation of high-pressure granulites of the Guaxupé complex, Southeastern Brazil. Geological Journal, 35(3-4):231-249. https://doi.org/10.1002/gj.859

Fuck R.A., Pimentel M.M., Alvarenga C.J.S., Dantas E.L. 2017. The Northern Brasília Belt. In: Heilbron M., Cordani U.G., Alkmim F.F. (eds.), São Francisco Craton, Eastern Brazil. Regional Geology Reviews. New York, Springer, p. 205-220.

Holland T.J.B \& Powell R. 2011. An improved and extended internally consistent thermodynamic dataset for phases of petrological interest, involving a new equation of state for solids. Journal of Metamorphic Geology, 29(3):333-383. https://doi.org/10.1111/j.1525-1314.2010.00923.x

Holness M.B. \& Sawyer E.W. 2008. On the pseudomorphing of meltfilled pores during the crystallization of migmatites. Journal of Petrology, 49(7):1343-1363. http://dx.doi.org/10.1093/petrology/egn028

Jamieson R.A., Unsworth M.J., Harris N.B.W., Rosenberg C.L., Schulmann K. 2011. Crustal melting and the flow of mountains. Elements, 7(4):253260. https://doi.org/10.2113/gselements.7.4.253

Janasi V.D. 2002. Elemental and Sr-Nd isotope geochemistry of two Neoproterozoic mangerite suites in SE Brazil: implications for the origin of the mangerite-charnockite-granite series. Precambrian Research, 119(1):301-327. http://dx.doi.org/10.1016/ S0301-9268(02)00127-4

Luth W.C., Jahns R.H., Tuttle O.F. 1964. The granite system of 4 to 10 kilobars. Journal of Geophysical Research, 69(4):759-773. https://doi. org/10.1029/JZ069i004p00759
Moraes R., Benetti B.Y., Motta R.G. 2015. Ultrahigh-temperature metamorphism in granulites with no "classic diagnostic" mineral assemblage, from the Socorro-Guaxupé Nappe, MG, Brasil. In: Hutton Symposium on Granites and Related Rocks, 8., Florianópolis. Program and Book of Abstracts, pt. 043.

Olsen S.N., Marsh B.D, Baumgartner L.P. 2004. Modelling mid-crustal migmatite terrains as feeder zones for granite plutons: the competing dynamics of melt transfer by bulk versus porous flow. Transactions of the Royal Society of Edinburgh: Earth Sciences, 95(1-2):49-58. https://doi. org/10.1017/S0263593300000912

Rocha B.C., Moraes R., Möller A., Cioffi C.R. 2018. Magmatic inheritance vs. UHT metamorphism: zircon petrochronology of granulites and charnockitic leucosomes of the Socorro-Guaxupé Nappe, SE Brazil. Lithos, 314-315:16-39. http://dx.doi.org/10.1016/j.lithos.2018.05.014

Rocha B.C, Moraes R., Möller A., Cioff C.R, Jercinovic M.J. 2017. Timing of anatexis and melt crystallization in the Socorro-Guaxupé Nappe, SE Brazil: Insights from trace element composition of zircon, monazite and garnet coupled to U—Pb geochronology. Lithos, 277:337-355. https://doi. org/10.1016/j.lithos.2016.05.020

Rosenberg C.L. \& Handy M.R. 2005. Experimental deformation of partially melted granite revisited: implications for the continental crust. Journal of Metamorphic Geology, 23(1):19-28. https://doi. org/10.1111/j.1525-1314.2005.00555.x

Salazar Mora C.A., Campos Neto M.C., Basei M.A.S. 2014. Syn-collisional lower continental crust anatexis in the Neoproterozoic Socorro-Guaxupé Nappe System, southern Brasília Orogen, Brazil: Constraints from zircon $\mathrm{U}-\mathrm{Pb}$ dating, $\mathrm{Sr}-\mathrm{Nd}-\mathrm{Hf}$ signatures and whole-rock geochemistry. Precambrian Research, 255(Part 3):847-864. https://doi.org/10.1016/j. precamres.2014.10.017

Sawyer E.W. 1998. Formation and Evolution of Granite Magmas During Crustal Reworking: the Significance of Diatexites. Journal of Petrology, 39(6):1147-1167. https://doi.org/10.1093/petroj/39.6.1147

Sawyer E.W. 2008. The Atlas of Migmatites. Ottawa, The Canadian Mineralogist Special Publication. $371 \mathrm{p}$.

Sawyer E.W. 2015. What leucosomes tell us about crustal differentiation. In: Hutton Symposium on Granites and Related Rocks, 8., Florianopolis. Program and Abstracts, K02.

Tedeschi M.F., Pedrosa-Soares A., Dussin I., Lanari P., Novo T., Pinheiro M.A.P., Lana C., Peters C. 2018. Protracted zircon geochronological record of UHT garnet-free granulites in the Southern Brasília orogen (SE Brazil): Petrochronological constraints on magmatism and metamorphism. Precambrian Research, 316:103-126. https://doi.org/10.1016/j. precamres.2018.07.023

Trouw R.A.J., Paciullo F.V.P., Ribeiro A. 1998. Tectonic significance of Neoproterozoic high pressure granulites in southern Minas Gerais. In: International Conference on Basement Tectonics, 14., Ouro Preto. Anais..., p. 69-71.

Weinberg R.F. |\& Hasalová P. 2015. Water-fluxed melting of the continental crust: A review. Lithos, 212-215:158-188. https://doi.org/10.1016/j. lithos.2014.08.021

White R.W. \& Powell R. 2010. Retrograde melt-residue interaction and the formation of near anhydrous leucosomes in migmatites, Journal of Metamorphic Geology, 28(6):579-597. https://doi. org/10.1111/j.1525-1314.2010.00881.x 